\title{
Destructive Behaviours and Leadership: The Source of the Shift from a Functional to Dysfunctional Workplace?
}

\author{
Anthony Geoff Sheard ${ }^{1}$, Nada Kakabadse ${ }^{2}$ \& Andrew Kakabadse ${ }^{3}$ \\ ${ }^{1}$ Fläkt Woods Limited, Axial Way, Colchester, CO4 5ZD, United Kingdom \\ ${ }^{2}$ The University of Northampton, Boughton Green Road, Northampton, NN2 7AL, United Kingdom \\ ${ }^{3}$ Cranfield School of Management, Cranfield, Bedfordshire, MK43 OAL, United Kingdom \\ Correspondence: Geoff Sheard, Flakt Woods Limited, Axial Way, Colchester, CO4 5ZD, United Kingdon. Tel: \\ 44-7801-724-717. E-mail: geoff.sheard@flaktwoods.com
}

Received: December 25, 2012 Accepted: January 14, 2013 Available online: January 29, 2013

doi:10.11114/ijsss.v1i1.31

URL: http://dx.doi.org/10.11114/ijsss.v1i1.31

\begin{abstract}
Destructive leadership behaviour often results in damage to the organisations that the individual is entrusted to lead. Although accurately pinpointing the type of destructive behaviour is difficult, this article seeks to offer suggestions as to why leaders spiral into such unattractive behaviour. After reviewing the literature, this paper highlights four drivers for destructive ways that people act based on detailed qualitative scenarios that involve how those who experienced such behaviour reacted and felt. The study reveals a noticeable human experience from which nobody can escape, and offers understanding of the study participants' experiences. Out of respect to the participants, the authors keep their identity anonomous. We drew our subjects from a cross-section of organisations that function internationally within one area of the manufacturing industry. The article presents a model comprising two dimensions: 1) the leader's attitude to the organisation he or she leads and 2) adequacy of his or her leadership capabilities. The models offer us understanding of the drivers of the destructive actions that the leader exhibits. Understanding allows us to provide managers with tactical methods to protect them against destructive behaviour and help them lessen the worst aspects of destructive behaviour in both their colleagues and themselves.
\end{abstract}

Keywords: leadership, destructive behaviour, discretion

\section{Introduction}

Some leadership positions are incredibly difficult for individuals to successfully perform. Leaders are, in effect, set up to fail. Others have impossible tasks trying to lead corrupt, incompetent organisations that resist appropriate processes. In such an environment, no leader can succeed. However, there is a difference between a failed leader and a derailed leader (Furnham, 2010, p. 234). Poor judgement or lack of ability characterises the former. Failure usually occurs with the absence of quality. On the other hand, the presence of quality characterises derailment. The derailed leader is potentially great- often graced with charm and determination. However, when something goes wrong, his or her self-confident and courageous behaviour can spiral out of control.

Leadership is a great art. It can test people to the limits of their ability, endurance and stamina. There are cases of exceptionally brave, skillful and wise leaders. Often they are mavericks who triumphed in unusual circumstances. Yet we can learn lessons from those whose star rose high, but then exploded into destructive behaviour damaging not only their own career, but also the organisation they were entrusted to lead.

Einarsen et al. (2007) studied destructive leadership and defined it as:

'the systematic and repeated behaviour by a leader, supervisor or manager that violates the legitimate interests of the organisation by undermining and / or sabotaging the organisation's goals, tasks, resources, and effectiveness and / or motivation, well-being or job satisfaction of subordinates' (p. 208).

In their analysis, Einarsen et al. (2007) reached a key conclusion that the above definition did not include intent. That is, destructive leaders may not intend harm, but due to their thoughtlessness, insensitivity or lack of confidence, they effectively do so. 
For Schaubroeck et al. (2007), the core issue is the effect of destructive leader behaviour on followers. The traits that they identify as causing follower distress are hostility and neuroticism. They argue that leaders prone to neurotic forms of negative emotions are likely to be callous, antagonistic, fearful of subordinate initiatives and prone to exhibit frustration. Such leaders are unwilling to communicate effectively with subordinates and are likely to limit subordinates' ability to cope with day-to-day problems.

Mumford et al. (2007) also studied the destructive behaviour of leaders and concluded that we can broadly categorise destructive leaders by their selective interpretation of information and reality distortion. This broad dimension suggests that biased self-serving appraisals of others and their intentions, especially the projection of negative intentions, may play an important role in destructive behaviour of leaders in general.

In this article we offer four examples that describe how destructive drivers can result in either reality distortion or group insularity. To begin, we offer a synopsis of background literature. We next provide an explanation of our methodology. We then offer four scenarios that demonstrate four types of destructive behaviour. We then review aspects of destructive behavior that resulted from our investigation and the types of destructive behaviour that we then found. The article next focuses on how to deal with the types of destructive actions, and then offers tactical recommendations for leaders to embrace in order to lessen the worst aspects of destructive behaviour in individuals. The article ends with a rundown of the study's most important answers.

\section{Background Literature}

The leading author on leadership, Warren Bennis, defines leadership as the 'capacity to create a compelling vision, and to translate it into action and sustain it' (Bennis, 1989). However, leaders are not born with the skills needed to create a compelling vision, translate it into action or sustain it, but rather they develop them (Bennis, 1989; Kakabadse \& Kakabadse, 2001; Kotler, 2003). The necessary drive and focus to develop these skills requires intelligence and hard work, but above all else, ambition (Kwon, 2003).

While ambition may drive the desire to lead, Bennis (1999, p. 18) suggests that 85 percent of a leader's performance depends on personal character, whilst Goleman (1998) argues that that leadership success or failure is most likely due to one's ability to regulate one's emotions in times of stress. Centuries ago, Aristotle (1941) too held that moral virtue comes about as a result of habit, with self-control developing within an individual as a consequence of that individual choosing self-controled acts.

Schyns and Schilling's (2013) meta-analysis of destructive leadership is self-consistent with Aristotle's conclusions (1941). Based on 57 previously published studies, Schyns and Schilling (2013) conclude that there is a high correlation between a leader's destructive behaviour and attitudes towards the leader. They then directly correlate negative attitudes towards a leader with subordinates' counterproductive work behaviour. Ambition can drive a leader to excel, but may become a dangerous attribute if it negatively influences how he or she interacts with others. The effectiveness of leaders depends on their relationships with others, as well as their ability to conceive a vision of the future, communicate it and through inspiring and motivating others, create the preconditions to realise that vision (Bennis, 1989; Kakabadse et al., 1998). How a leader interacts with those with whom they work and the border organisational environment is therefore important.

Leaders are in a position of trust, marshalling resources, in effect, without supervision. Consequently, most of their decisions have moral consequences. Jones (1991) introduced the concept of perceived moral intensity in ethical decision making. Jones believes that people become more worried about ethical situations that influence people nearby instead of those with whom they have little or no interaction. In effect, people are more concerned about those nearer to them physically and emotionally than those who are remote.

Further, they tend to react more strongly to what they perceive as an injustice if it has immediate effects as opposed to an injustice whose effects will impact in the future (Jones, 1991). For example, a CEO may feel some responsibility for the issues that occur with immediate organisational problems, but less for those that may take effect in the long run. Thus, a decision will have high moral intensity if the event's proximity is close to the decision maker.

According to Jones (1991), perceived moral intensity influences the recognition of a moral issue, the making of moral judgements, the intention to act and behaviour. Scholars have linked the dimensions of moral intensity to the recognition of moral issues, moral evaluations and moral intentions, with May and Pauli (2002) defining three components of moral intensity:

1. concentration of effect,

2. probability of effect and 
3. proximity,

where the closer in proximity an individual is to the situation, the greater the perception of ethicality (Carlson et al., 2002).

Research has shown that the magnitude of consequences moderate the relationships between attitudes, subjective norms and leaders' environmental ethical decision intentions (Flannery \& Douglas, 2000). Moreover, as an issue becomes less personal, leaders tend to allow different factors to play a role in the decision-making process. Allowing various factors to play a role in decision-making could diminish the situation's moral intensity (Carlson et al., 2002). However, it appears that the probability of effect and concentration of effect were not significant predictors of moral intensity (Carlson et al., 2002). Membership of an in-group, magnitude of consequences, social consensus and probability of effect determine whether we perceive an act as ethical or unethical (Singer \& Singer, 1997).

We can find a theoretical grounding for the antecedents of destructive behaviours and leadership, namely leadership hubris and narcissism, in the extant literature on decision-making, charismatic and transformational leadership. We can consider the choices made by those trusted to lead in terms of orientation (Svensson \& Wood, 2006) and capability (Sheard et al., 2009, p. 128). We may conceptualise the orientation of organisational actors as basic attitude, beliefs and feelings towards their role as a leader. We perceive capability of organisational actors as the ability to initiate and undertake leadership action.

Kets de Vries (2010) has comprehensively studied the basic attitude, beliefs and feelings of leaders and concludes that most leaders are able to arouse primal feelings in their supporters. A consequence of reawakening primitive emotions in followers is that leaders can be pathologically destructive or intensely inspirational (Kets de Vries, 2010, p. 7). Furnham (2010) studied leadership derailment and observed that destructive management is not altruistic. It pays more attention to the leader's wants than the followers' needs (Furnham, 2010, p. 22). Further, destructive results do not just result from destructive leaders, but vulnerable supporters also cause them. A leader's degree of selfishness will affect followers, and in turn, the followers' response will constitute a form of feedback that either moderates or exacerbates destructive leader behaviour.

In contrast to attitude, beliefs and feelings is a leader's ability to lead successfully and efficiently- his or her competence. Some scholars have argued that the historic focus on competencies fails to define competencies in terms of the organisation, its culture, its market place and business environment (Stuart \& Lindsay, 1997). As such, the traditional view of competencies has focused on the skills and behaviours that a leader requires to perform a job. However, the ability and willingness to apply competencies within a particular context is also important.

We can define capabilities as the ability and willingness to apply competencies within a particular context (Sheard et al., 2009, p. 130). We may conceptualise context in terms of demands, constraints and choice. Any individual in any organisation will have demands placed upon them, and simultaneously a set of constraints (Lowe, 2003). Constraints and demands that occur with any particular situation limit the available choices. Within the constraints imposed upon them, leaders are able to exercise choices when deciding how to comply with the demands placed upon them. Therefore, we may deem leaders capable when both willing and able to apply their competencies within the context not only of the demands made on them, but also the constraints imposed upon them.

The development of appropriate competencies and the application of those competencies within the context of the demands and constraints under which a leader operates are undeniably challenging. Leaders have to assess a situation, analyse data and make plans. More importantly, they have to make wise, timely, informed and often risky decisions (Furnham, 2010, p. 199). They need to be good at problem solving, efficient and accurate, whilst also articulating their position and drawing on past experience. Some leaders are quite simply not up to the job, instead focused on their own self-importance. Lacking the necessary capability, they in effect, convince themselves that they are great leaders, but in reality, are deceiving themselves and those around them.

Blaming others for their problems is an approach that some adopt who lack the necessary capability to lead. They become suspicious and mistrustful of those who are bright enough to cope, and become progressively more paranoid. A degree of paranoia is not necessarily a bad thing as we associate many paranoid tendencies with good management: alert, careful, observant and tactical (Furnham, 2010, p. 157). Further, a factor in the demise of executives is what they recognise in hindsight to have been naïve assumptions about the motives of others. As such, Kramer's (2002) observation seems relevant- a moderate form of suspicion can in many cases prove highly valuable, a state Kramer (2002) refers to as 'prudent paranoia'. However, when paranoia spirals out of control, a leader's behaviour becomes destructive as he or she becomes progressively more argumentative, belligerent, hostile, secretive, stubborn and consumed with mistrust. 
By definition, capable leaders are effective leaders, and when considering what makes an effective leader, Drucker (2004) concluded that whilst they differ widely in their personalities, strengths, weaknesses, values and beliefs, they all have one thing in common: they get the right things done. Getting anything done is challenging, with each leader developing individual approaches to the decision-making process and subsequent management of people. Some highly effective leaders derail into dysfunctional behaviour by developing patterns of attitudes and behaviours that whilst highly effective, are anti-social. They result in the leader becoming a sociopath.

Sociopaths may have a well developed conscious and normal capacity for empathy, guilt and loyalty, but their sense of right and wrong is based on a different set of norms and expectations to those of a better adjusted individual. We might describe many criminals as sociopaths (Boddy, 2011, p. 153). The result is a Machiavellian approach to leadership where the ends justify the means, with a lack of consideration for the right of others. Clever and presentable, sociopaths can be highly effective and therefore successful leaders; however, their lack of consideration for others' rights or remorse for the impact of their behaviour on others makes them ultimately destructive leaders.

As we previously stated, leaders can be pathologically destructive or intensely inspirational, but what causes leaders to be one or the other? Kets de Vries has considered this question and concluded that it boils down to how narcissistic the leader in question is (Kets de Vries, 2010, p. 7). Campbell et al. (2004, p. 298) identify two key elements of narcissism: "a positive, inflated, and agentic view of the self; and a self-regulatory strategy to maintain and enhance this positive self-view", and argue that narcissism can express itself in various ways. For example, narcissists may believe that they are special, entitled to more positive outcomes in life than others, more intelligent than they actually are, and better in the exertion of power and dominance than others (Raskin \& Hall, 1979; Raskin \& Terry, 1988; Raskin et al., 1991; Campbell et al., 2004).

We can relate narcissism positively to self-esteem, high levels of anger and aggression after negative feedback, and high levels of confidence in one's own abilities (Campbell et al., 2004). Narcissists tend to rate themselves more highly than the outsider would objectively warrant on an array of agentic dimensions, including intelligence, creativity, competence and leadership abilities (Kets de Vries \& Miller, 1985; John \& Robins, 1994; Judge et al., 2006), which then gives them above normal confidence about their abilities, resulting in over-confidence (Campbell et al., 2004).

Although we can positively relate narcissism to self-esteem, at their core, narcissists live with the assumption that they cannot reliably depend on anyone's love or loyalty. They feel that they must rely on themselves rather than others for the gratification of life's needs. Whilst pretending to be self-sufficient, in the depth of their being they experience a sense of deprivation and emptiness. To cope with these feelings and, perhaps, as a cover for their insecurity, narcissists become preoccupied with establishing their adequacy. Striking in the behaviour of these people is their interpersonal exploitations. Narcissists live under the illusion that others are entitled to serve them and that their own wishes take precedence over those of others. They think that they deserve special consideration in life.

Everyone needs an element of narcissism in order to function effectively. Interestingly, amongst those who have some narcissistic tendencies, we find some of the greatest leaders. However, studies of leaders with excessive narcissist tendencies have shown that leaders often exhibit common fallacies. These include an egocentrism fallacy (a belief that only one's own interests are important), an omniscience or over confidence fallacy (hubris or a belief that they know everything) which is then related to the invulnerability fallacy, (a belief that they are able to get away with everything) and the unrealistic optimism fallacy (a belief that everything will work out fine). As a direct consequence, leaders with excessive narcissistic tendencies miscalculate risks when they make decisions (Lovallo \& Kahneman, 2003; Sternberg, 2003, 2007; Gombola \& Marciukaityte, 2007; Ben-David et al., 2010). Although confidence can help leaders to realise their vision and achieve corporate goals (Hiller \& Hambrick, 2005; Li \& Tang, 2010), the downside and the potential risks are dysfunctional leader behaviour and increased organisational risk (Hayward \& Hambrick, 1997).

\section{The Study}

In this study of destructive behaviour as human action, we used Sheard et al.'s (2013) narrative approach. Social scientists normally use narrative as an interpretive approach. The methodology involves storytelling (Rhodes \& Brown, 2005), where the story examines how persons or groups interpret events and actions in their lives, whilst inquirers tell the informant's story through ethnographic methods like observation and interviews. This methodology helps to study subjectivity, for example, individual and cultural influences on identity and the human condition (Polkinghorne, 1988).

Since the start of the narrative movement in the late 20th century, scholars have perceived language to deeply 
constitute reality rather than serve as a device for establishing meaning. Stories do not mirror the outside world, but are constructed, rhetorical and interpretive (Riessman, 1993). Stories pay attention to experience which is of interest in narrative. This has happened since cognitive psychology acknowledged narrative as reflecting a cognitive structure (Polkinghorne, 1988).

Similarly, therapists in psychoanalysis pay attention to clients' narrations and convert these into narratives that are more adaptive, coherent and functional (Polkinghorne, 1988). We listen to our study participants' stories and retell their narratives in a more coherent framework. We also use narrative therapy in order to move the narratives' dynamics to attain more socially practical behaviour.

An aspect of the narrative therapy was the identification of antecedents of hubris, a narcissistic personality, a recent series of successes and a study participant's belief that he was exempt from the rules (Hayward \& Hambrick, 1997; Kroll et al., 2000). The extant literature identifies the antecedents of "narcissistic" or "pathologically self-absorbed" behaviour as:

- direct and indirect reinforcement (environmental factor) (Judge et al., 2006). Padilla et al. (2007) suggested that some environments are simply more likely to facilitate toxic leadership. Facilitative environments include those that are unstable with many perceived threats, organizations with low or poor cultural values, organizations that have a lack of checks and balances, and organizations that are perceived as struggling and appear ineffective and inefficient and organisations in crisis.

- a 'pervasive pattern of overt grandiosity, self-focus and self importance behaviour, displayed by an individual or group of individuals' (American Psychiatric Association, 2000; King, 2007, p. 184). Leaders who 'present an unusual degree of self-reference in their interactions with other people, a great need to be loved and admired by others, and .... a very inflated concept of themselves and an inordinate need for tribute from others. ... In general, their relationships with other people are clearly exploitative and sometimes parasitic. It is as if they feel that they have the right to control and possess others and to exploit them with no guilt feelings' (Kernberg, 1995, p. 17).

\section{Methodology}

Five CEOs plus three subordinates, all with significant profit and loss accountability and each running global organisations in a single sector of manufacturing industry, participated in this study. This served as an advantage because they all sat on the Board of the same not-for-profit trade association. The trade association meetings served as the opportunity to meet with and interview the study participants. As we often see in traditional manufacturing industries, those holding leadership roles and serving on the trade association Board were exclusively white males between the ages of 45 and 65 . The study sample is ideal and well applicable in situations where studying sensitive issues, such as relatively private matters that necessitate insider knowledge of key people for the research (Biernacki \& Waldorf, 1981).

In the interview process, a participant recalled his time working with leaders who would take action that damaged the organisations that they lead. The narrative approach highlighted the subjects' individual choices and situations which illuminated many forms and aspects of destructive behaviour and the influence of feelings and situations in the respective conflicts.

One of the authors accessed the study participants when they joined the trade association's Board. The intent for the interviews was initially educational, in order to understand the trade association's history to gain insight into, and understanding of the existing Board challenges. Interviews with study participants began with open questions about the types of challenges that the trade association faced. As study participants began to unwind, dialogue would transition to how they came to serve on the Board and then how they had 'climbed the ranks' before their invitation to serve on the Board.

As study participants talked about how they had climbed to the top of their respective organisations, the interviews increasingly focused on destructive behaviour. The challenges of working with and for those individuals who displayed such behaviour emerged from the interviews ethnographically. The authors wanted the first interview round to provide some insight into the trade association's issues and challenges with which the Board was involved. However, the interviews unfolded in an unexpected way. The participants ended up telling their life stories and discussed their career-long problems regarding the destructive behaviour of others.

We interpreted the interview transcripts using an open coding system. Themes emerged from this which we adopted using an interpretive, inductive approach to preserve the 'wholeness' and 'meaningfulness' of the data (Dey, 1993; Bryman \& Burgess, 1994). Data clusters emerged from this approach without pre-specifying the categories (Miles \& Huberman, 1984; Lincoln \& Guba, 1985; McCracken, 1988). This process follows 
qualitative content analysis methods of reduction and interpretation (Rubin \& Rubin, 2005).

We base the findings on the narratives that emerged from the eight study participants. We interviewed them three different times with each meeting focusing on a specific experience. Accordingly, we base our findings on 24 narratives. After the interviews, we interviewed the people who the participants talked about in their narratives. Our study participant choice gave us the opportunity to interview them individually. Selecting people who sat on a trade association Board allowed us to choose participants who had spent the majority, if not all of their career, within the same area of manufacturing industry. By examining the list of attendees at various trade association functions, we could arrange to be in the same place at the same time as some of those described.

Even though reaching the people who the study participants described was difficult, our success in reaching these people is a major methodological strength. In total, we located and interviewed ten people who the study participants identified. We reasoned that interviewing the individuals about their taking action that resulted in great and lasting damage to the organisations that they lead probably would not bring about either a positive or helpful response. Even though it was not easy to conduct these interviews, by focusing our queries around an exact period in their life, the participants were able to provide us with some significant details regarding events during their career.

Upon completing the interviews, analysing the data and identifying developing themes, we pooled study participant narratives into four case studies. Each case study talks about one of the study participant's real life occurrences. Each relays a story about a single leader who displays one form of destructive behaviour from the standpoint of an amalgamated character, Harry, a go-getter with tremendous abilities. Vigorous and young at heart, this 42-year-old director has a reputation for unyielding effort. Case studies often use an amalgamated character to protect the study participants' identity in order to maintain anonymity. The case studies echo a cognitive structure within which Harry both represents the study participant's combined experiences and also a sane voice within each organisation.

\section{Discussion of Results}

Two similar yet autonomous themes resulted from the data analysis: 1) leadership orientation and 2) leadership capability. We used these themes to classify four forms of destructive behaviour (see Figure 1). Study participants named orientation as a leader's basic attitude, beliefs or feelings in relation to a particular subject or issue. Therefore, this model talks about processes that are situated in the thoughts and beliefs of the involved individuals. When those occupying a leadership role display these processes, the four types of destructive behaviour are:

1. Deluded behaviour: self-oriented and with low leadership capability;

2. Paranoid behaviour: oriented towards others and with low leadership capability;

3. Sociopathic behaviour: oriented towards others and with high leadership capability; and

4. Narcissistic behaviour: self-oriented and with high leadership capability.

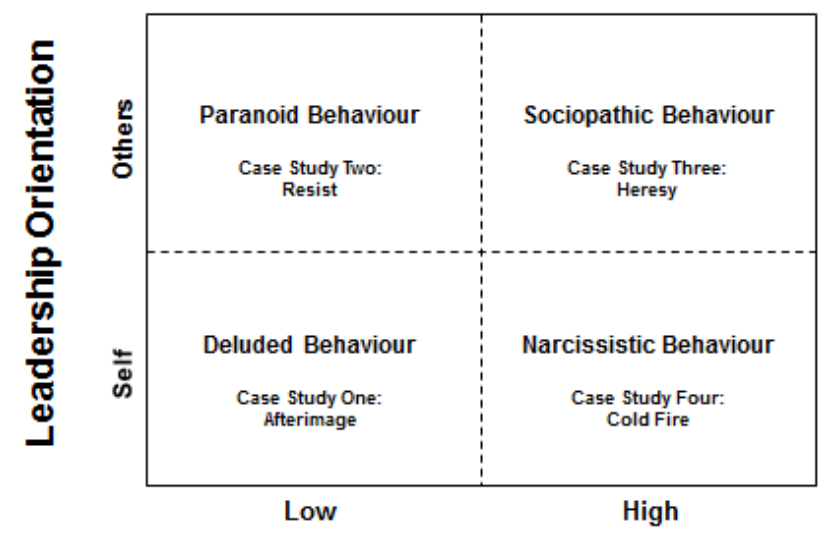

\section{Leadership Capability}

Figure 1. Destructive behaviour model characterising behaviour in terms of the manager's leadership orientation and leadership capability 
The deluded leader is in denial about him or herself, the constraints around his or her work and the details of past occurrences. We discovered that the deluded leader displays destructive behaviour in his or her inability to make timely decisions and most simply by an inability to get things done. The paranoid leader is suspicious of others, always ready to fight seeming threats and with extreme worry for concealed motives and unique meanings. We found that the paranoid leader exhibits destructive behaviour that is characterised by an intense attention to spin, rationalised by an all pervading mistrust of others. The sociopathic leader consistently disregards and violates other people's rights. We found that the sociopathic leader exhibits destructive behaviour that is characterised by indifference to having hurt or mistreated others and a consistent lack of remorse. The narcissistic leader is resistant to change. He or she knows that their way is best and have an inability to recognise his or her many limitations. We discovered that the narcissistic leader displays destructive behaviour that is characterised by a lack of capacity to learn from others or experience, and a refusal for accountability and hence, responsibility.

The above model is applicable to the study participants' experiences, but did not comprise a hierarchical endeavor. Leaders who display one of the four forms of destructive behaviour, which the model identifies, did not generally transform over time, and were unable to change. Overall, participants did not seem to learn from their experiences in spite of, in some cases, significant proof that their own behaviour was detrimental not only to the organisation that they were leading, but also their respective career opportunities.

\subsection{The Deluded Leader}

We portray the deluded leader as one with destructive behaviour that is focused on his or her perceived personal needs and is an individual who occupies a leadership role despite his or her lack of capability. An inability to make timely decisions and an inability to get things done characterises his or her behaviour.

\section{Case Study Part One: Afterimage}

Harry was slightly bemused as he sat listening to the Human Resource Director and Chief Executive Officer discussing the new Operations Director, Richard, who they had appointed that morning. They seemed most impressed that Richard had gold cards with three different airlines. This did not seem to Harry like a qualification relevant to running a factory. In fact, when he came to reflect on the necessary requirements to run a factory, physical presence seemed like a mandatory prerequisite. Anyone with three airline gold cards was, by definition, not in any one place for any length of time.

Three months later Harry returned to his office after a business trip to find Richard installed in his new role. At the Board meeting that morning, the Chairman gave Richard a platform from which he could speak with passion about those things that he believed most important. Undoubtedly, the speech was impressive, as Richard interspersed his monologue with examples of past adversity, and how he had forged pathways through hindrance and ultimately triumphed. After the Board meeting Harry was about to comment to Richard that his address, although impressive, had noticeably lacked any mention of the factory that he was now responsible for running. Specifically, there was no mention about how he intended to address poor, and deteriorating, on-time delivery performance. However, before he could intervene, the CEO stepped in and ushered Richard away.

Over the next month, Harry became increasingly concerned about their new Operations Director's competence as Richard initiated a host of initiatives, each in its own way promising, but disconnected from one another. There was no strategic link between the initiatives and each appeared to Harry to be over dependent on specific individuals. As conflict between those individuals emerged, the initiatives effectively stalled with no follow through. It seemed to Harry that Richard had problems with his interpersonal relationships, difficulty connecting with staff and an inability to make difficult judgment calls.

It was only a matter of time, Harry thought to himself, in retrospect. Harry had been working on a critical contract with truly punitive penalty payments for late delivery. One of his own staff very quietly advised him that he might find it instructive to visit the factory and ask a few questions about how this particular contract was progressing. Within a minute of doing so, Harry was at the eye of a storm, as the operations managers responsible for different parts of the factory blamed each other for what would surely be not just a late, but disastrously late delivery. Richard was notable only by his absence, and consequently, it was Harry who 'forged a pathway though hindrance and ultimately triumphed' absolutely exhausted 37 hours later.

After some sleep, Harry returned to the office, where he found Richard waiting for him with some plausible excuse for his absence, incredulous that the crisis had arisen, yet delighted that the world had proven once more that bad things happened when he was not around. Truly, he was indispensable. Later that day the CEO dropped by Harry's office to advise him. First, Harry needed to take a shower and shave and second, Richard had left the firm in order to have more quality time with his family. 
It was difficult to entice Richard to discuss the case study happenings. These took place over a year before his interview and although he was happy to talk, encouraging him to focus on specifics and give more than vague generalisations was difficult.

\section{'I see myself very much in the role of Director. I provide direction. If I allow myself to get drawn into the day-to-day detail of organisation life, then I'm going to lose sight of the big picture. The clue is in the name, Operations Director, not Operations Manager or Operations Supervisor. I know that my experience can be invaluable, that on occasions it is only me that has the real world capability to resolve the most difficult problems, but my intervention should be the last resort, not the first. If I am always available at the first sign of trouble, how will others learn? However, I do concede that with my experience, it is not surprising that I am in such demand.' (Richard).}

The case study shows that destructive behaviour does not always occur in a leader who appears as either aggressive or as a bully. Although impossible to verify, a review of Richard's CV indicated that he had spent his career within established and stable organisations that could, in effect, function well without him. As such, he was able to take credit for the work of others, and in the process, build a most impressive CV. In this instance, it is clear that thoughtlessness and insensitivity resulted in damage to the organisation that was never intended. Richard genuinely believed that he was a great leader, but that was simply not true.

\subsection{The Paranoid Leader}

We portray the paranoid leader as one with destructive behaviour that is embedded in relentless skepticism about other people's motives. Despite having attained a position where they are required to lead others, they have little capability to do so and always find a way to blame their problems on others. They are typically passive-aggressive, hypersensitive, cold and unemotional.

\section{Case Study Part Two: Resist}

Globalisation. 'What exactly does it mean in practice?' Harry thought to himself. That week, Harry joined the Board of a not-for-profit organisation set up 50 years ago for the sole purpose of writing standards. The prevailing view within the organisation was that globalisation was the process of adopting the same standards in all global regions. The organisation had originated in Canada. This in itself was not a bad thing, but until about five years previously it had for all practical purposes been a North American standard writing organisation. Although the emerging markets in Asia were willing enough to embrace the organisation's standards, European markets were not. Harry was all too well aware of this, himself British and active in the European standards writing community.

As is often the case with not-for-profit organisations, the Board comprised volunteers. An Executive Director, Brenda, handled day-to-day operations. As he had only just joined the Board and not yet attended his first Board meeting, it was with some surprise that Harry received a call from Brenda asking that he accompany her to a meeting in Belgium. Representatives from 50 European groups, companies and institution were concerned about a forthcoming European Commission Directive. They wanted to discuss how to develop new standards to facilitate compliance with the Directive. The meeting proved challenging, as with so many people in the room it was hard to agree to actionable specifics. The European delegates would revert to their native languages when discussions became heated making it impossible to follow what they were saying. Brenda remained polite, quoting rules and regulations, expertly avoiding questions and evading all attempts on the part of representatives to get a commitment from her on specific courses of action.

The meeting broke up without agreement. Three weeks later, Harry learned that the Belgium meeting representatives had formed their own standards organisation. At Harry's first Board meeting, the Chairman was not only angry, he was apoplectic with rage. Some of the representatives had called him to say that believing Harry could become a bridge between North America and Europe, they had gone to great trouble to organise the Belgium meeting. They felt that their time had been wasted. Brenda lectured the Board members and Chairmen on the motives of the representatives, and how quickly they had set up a competitor organisation constituted proof of their disloyalty. The Board voted unanimously to terminate Brenda's contract of employment.

Speaking about three months after her dismissal, Brenda appeared willing enough to cooperate, however with a tendency towards paranoid behaviour. She was suspicious, mistrustful and looking for hidden motives. It is therefore entirely possible that what she said was not what she actually thought. 
'I have spent my entire carrier in association management. If you go back more years then I care to mention to when I started out, it was largely an amateur affair, but with the anti-trust laws and professional lobbying today, a part time Board really needs a professional association manager. The Board members do present a challenge, particularly having a new Chairman each year and therefore a new boss. Most of them really have no idea what they are doing and you just have to sit it out and hope the next one is better.'(Brenda).

The case study demonstrates that Brenda did not value the force of her behaviour. Choosing to 'sit it out' was a way of rationalising inaction, and although all leaders must take care, they must be prepared to take action. To simply manage the status quo, and wait for the volunteer Board members to move on and out constitutes a form of destructive behaviour that degrades an organisation over time as they miss opportunities and competitiveness ebbs away as the organisation's external environment evolves.

\subsection{The Sociopathic Leader}

We portray the sociopathic leader as having destructive behaviour that manifests itself through extreme antisocial attitudes. A complete disregard for the rights of others or their duty of care towards those who report to them characterises his or her behaviour. Perhaps paradoxically, this disregard for others helps to make him or her more effective in a leadership role, as he or she 'wastes' no time worrying about the impact of any course of action on those who must actually implement it.

\section{Case Study Part Three: Heresy}

Harry was not looking forward to the forthcoming meeting. The Chief Executive and his entourage of accountants would be arriving for a quarterly review in a week's time, and staff morale was at an all-time low. However, the local General Manager, Fred, was in his element. The company had ruthlessly implemented a clean desk policy in the offices, and in the factory, the local scrap metal merchant was in permanent residence, removing anything that was not actually screwed down. The smell of new paint was everywhere. 'Surely', Harry thought to himself, 'the Chief Executive could not be so stupid as to actually be taken in?'

As the Group Engineering Director, Harry had no direct authority over any individual site. He just happened to be based at this particular one. However, Harry was concerned about staff morale as an alarming number of people had been signed off sick with stress-related illnesses. Consequently, the engineering department was understaffed and they had not completed any research or development for the last nine months. Sooner or later this focus on squeezing costs must manifest itself in falling product sales. Despite Harry's reservation, the quarterly review was a great success. The offices and factory were almost clinically clean, and without having spent any money on research, development or capital equipment that financial year, profit was well ahead of budget.

As Harry walked back to his office after the review, he could not help but wonder how Fred had become such a skilled and habitual liar. The lies he perpetrated were not blatant. If they were then he would have been caught. Typical Fred would leave the talking to his 'tame accountant' to keep the audience emerged in numbers, and if anybody asked non-financial questions, he would respond with a generalisation, stating 'facts' that, in reality, were only his opinions. If challenged, he would retort with a pre-meditated and articulate compelling defence of the 'truth'. Combined with his pattern of opportunely not remembering things that he had said or to which he committed, the fictional reality that Fred presented was almost impossible to expose.

Fred maintained the fiction that he presented to the Chief Executive in part because staff members were afraid of him. The company was struggling through an economic downturn, and there were few other jobs in the area. It was important to hang onto the job you had. So, Fred was able to bully and manipulate staff. This was sometimes overt in the form of swearing, shouting or general physical intimidation. However, the worst bullying was under the radar. Fred enjoyed nothing more than belittling, criticising and undermining the staff, manipulating their fears and emotions of guilt.

It was with some surprise when one week later Harry learnt that the Human Resource manager, Jane, was leaving. Harry and Jane had always gotten on well, but she had made up her mind. She had taken a lower paid job 'at a company that actually welcomes human beings'. Unfortunately for Fred, the Chief Executive also got on well with Jane, called her in an effort to persuade her to stay and for his trouble got a two hour lecture on how the site was really run.

It transpired that Jane had been secretly keeping a log totalling 47 pages of every employee complaint about Fred over the last year. Two days later the Chief Executive marched into Harry's office unannounced. The 
conversation was brief. He had confronted Fred that morning and accepted the letter of resignation that Fred had written as he had watched. Harry would be the acting General Manager whilst he found a permanent replacement. The next quarterly review would be in 10 weeks, and he did not want to smell new paint when he arrived.

One month after what transpired in this case study, we asked Fred to comment about his time as General Manager. It was not clear from the conversation if Fred was simply incapable of remorse, had a reckless disregard for others or had simply managed to block it out, thus ignoring both his duty of care as a General Manager and a wider obligation to the staff who reported to him.

'I am a people person. I get really upset when people are treated badly. I am not taking about myself. If you are the senior manager on a site or in a business then you live by the sword and can expect to die by the sword. It's necessary sometimes to get things done to implement change. That is my strength. I can turn a failing business around. I know how to motivate people irrespective of if they want to be motivated of not.' (Fred).

The case study illustrates the effect that extreme antisocial attitudes and behaviour can have on others. There is no question about Fred's leadership capability. He was highly capable, however, the way he treated others was shameful. He was underhanded, deceitful, lied and thought nothing of conning others. When he met with resistance or objection he would become irritable and aggressive and fly into a temper. At no point during our interview did he show remorse, characterising those who were signed off sick with stress-related illness as weak. He utterly lacked emotional intelligence, or empathy of any kind.

\subsection{The Narcissistic Leader}

We portray the narcissistic leader as having destructive behaviour that an inability to recognise their many limitations drives. They are highly energetic, outgoing, competitive, supremely confident and ambitious with a deep and abiding sense of entitlement. Preoccupied with how to find and use power, they make highly capable leaders, but do not learn from others or previous experience. Consequently, they are prone to fail in the most spectacular fashion.

\section{Case Study Part Four: Cold Fire}

The meeting, Harry thought to himself, was appropriately named: It was a Board meeting, and he was bored as were the other 15 people waiting for the Chairman, Bill, to join them. Twenty minutes late, Bill swept into the room without apology or excuse. It seemed to Harry that Bill regarded himself as special, and as such, entitled to behave as he liked. Today he liked to keep the extended Board waiting. The executive suite layout facilitated such behaviour. Bill had both an outer office where his fearsome personal assistant awaited anyone foolish enough to approach without an appointment, and a door between his inner-office and the Board room. Emerging through that door, he took his place at the head of the table with the sun shining through the plate glass windows behind him as he surveyed his subjects.

Bill had called the Board meeting to review strategy relating to a new acquisition in Denmark. The company could rationalise product ranges, downgrade the Danish factory to a sales office and sell the Danish site. The site was worth more than they had paid for the new acquisition, and the company could manufacture the products made in that factory in England and ship direct to customers around Scandinavia.

No-one argued. Bill's motivational approach was well known. When things were going well he was humorous and would grant personal favours; however, he was like a spoilt child, needy and self-absorbed. When things do not go his way, when he did not receive the recognition or praise that he so clearly deserved, he sulked. It was well known that Bill could hold a grudge with a superhuman intensity, so it was best not to upset him. In fact, the longer serving Board members would routinely tell Bill how brilliant he was and how the company simply could not do without his leadership and ideas.

The strategy to close the Danish factory was simple enough in theory, but proved rather more difficult to implement in practice. The unions in Denmark were ready for a fight. This gave Bill a focus for his anger, which as the Engineering Director, suited Harry well as it resulted in Bill having no time for him. Nevertheless, Harry was concerned about the engineering approach that the Scandinavian facility had historically taken. The products from the Danish factory did essentially the same job as the English equivalent, but a British Standard required a bolted construction. In contrast, it was custom and practice to supply a welded construction in Scandinavia.

As Bill mobilised his troupes to prepare for battle, Harry immersed himself in the practical detail of how the English factory would actually make these Danish products. As the English factory sub-contracted all welding, it could not make them, a point Harry felt compelled to mention to Bill. The discussion did not go well, with Bill 
subjecting Harry to a long lecture about organisational change and how to implement it.

Three months later the Danish factory closed its door for the last time. The local management team, in collusion with their local suppliers, promptly opened for business selling the welded products that the local market wanted. Three months after the closure, orders from the new Danish sales office were $90 \%$ down from the previous 3 months' pre-factory closure. The Danish sales team blamed engineering. The Scandinavian market would not accept products with a bolted construction. Bill was furious, stormed into Harry's office and fired him on the spot.

Although leaders with a tendency towards narcissistic behaviour are supremely confident and aware of their strengths, their self-esteem is fragile. Consequently, they tend to form relationships specifically designed to enhance their self-esteem and are profoundly wounded by any suggestion that they have significant weaknesses or shortcomings. As such, it is likely that Bill and his sycophantic inner circle simple re-wrote history, characterising the sale of the Danish site and the money made as a triumphant success and their short-lived Engineering Director as incompetent.

'I have run this business for 18 years, and am proud to say that as a consequence of my efforts it has been consistently profitable. I know my business, and I know how to cover the risks associated with doing business. Take, for example, the Danish acquisition. I was able to add real shareholder value through the acquisition of that business and subsequent sale of the factory.'(Bill).

The case study illustrates what an inability to learn from your mistakes or from others really means in practice. An acquisition that descended into what was a barely disguised disaster occurred as a direct consequence of Bill's grandiose sense of self-importance and arrogance. In reality, he destroyed shareholder value, and squandered an opportunity to work with a Danish management team that paradoxically was initially enthusiastic and positive about the merger. An over sensitivity to set-backs, real or imagined was masked with a defiant counter-attack that, in this example, drove a narcissistic leader's destructive behaviour.

\section{Characterising Destructive Behaviour}

The four parts of the case study demonstrate how leadership orientation and leadership capability unite to make possible the definition of four markedly diverse types of destructive behaviour. The scenarios also show that leaders with destructive behaviour have a gamut of character traits. Note that we should not use the scenarios to conclude that we can correlate one type of destructive behaviour with a certain character trait.

The destructive behaviour model's capability dimension portrays leadership capability as either low or high. Within the context of the destructive behaviour model, the difference between competence and capability is critical. The term competences refer to specific skills. Competencies are inherently portable and individuals can take them from organisation to organisation. In contrast, capabilities are immediate and far more contextual. As a leader moves from one organisation to another or from one job to another within the same organisation, competencies may remain relevant, but current capabilities are almost certainly undermined. We define capabilities as the aptitude and motivation to apply competencies within a particular context (Sheard et al., 2009, p. 130), and consequently a leader's capability may be high in one context, or a series of contexts, resulting in rapid career advancement, but low in another.

When we think about how a leader who lacks capability views their own capability in the context within which he or she finds him or herself, it is evident that the deluded or paranoid leader fails to see either the need for organisational change or if he or she does, he or she fails to appreciate the associated challenges of implementing the necessary change. In contrast, the sociopathic or narcissistic leader sees clearly that change is both necessary and central to his or her role as leader, but lacks any appreciation of the impact of that change on others, particularly subordinates.

The orientation component of the destructive behaviour model portrays leadership orientation as orientation towards self or others. The centrality of self and ensuring that the world rightly revolves around them is the deluded and narcissistic leader's focal point. However, a paranoid and sociopathic leader's world view concentrates on manipulation of a peripheral actuality that is something that he or she will change or fear as he or she simply does not understand it.

The four scenarios profiled leaders who did not proactively set out to harm either the organisation in which they lead, or the people in it. However, due to their thoughtlessness and insensitivity, their behaviour was ultimately destructive. However, Parts One and Four highlighted leaders who were also selfish. Their interests were in fully embracing the privileges and perks that came with their position to evade the boring and wearisome business of 
participating in the in-depth conversations, debate and negotiation that occurred with creating a common ground that all could embrace- a predictable facet of any leader's role. Parts Two and Three's profiled leaders who thought that they could act as they pleased because their rank, even though there were clear warnings about the impending disaster their action would bring down.

The four scenarios profiled leaders who did not set out to damage the work place that they were leading. However, their thoughtlessness and insensitivity resulted in them effectively doing so. As such, the scenarios are consistent with Einarsen et al.'s (2007) key conclusion that leaders prone to destructive behaviour do not intend harm. Further, Schaubroeck et al. (2007) observed that leaders prone to destructive behaviour limit subordinates ability to cope with day-to-day problems. Each case study illustrates how subordinates were aware of the damage unfolding, but despite their capability in their own right, they were unable to effectively intervene.

Mumford et al. (2007) observed that we can characterise leaders prone to destructive behaviour by their selective interpretation of information and reality distortion. Consequently, centering on a leader's inclination towards disproportionate concern with his or her own glorification or naïve assumption that he or she can impose his or her will on others without consequence can help us differentiate between leaders with an orientation focused on self or others.

When scrutinising the scenarios regarding leadership capability, Parts One and Two's profiled leaders are not interested in or do not appreciate those that they were allegedly leading. However, Parts Three and Four's profiled leaders were fully engaged with both the organisation that they were leading and the people in it, but were callous and indifferent to the impact of their behaviour.

When studying leadership derailment, Furnham (2010) observed that leaders prone to destructive behaviour have a selfish orientation, focusing more on their own needs rather than the needs of followers. Kets de Vries (2010, p. 7) concluded that the difference between an intensely inspirational leader and a pathologically destructive leader is the degree of narcissism in the personality in question. Leaders with unhealthy levels of narcissism in their personality believe only one's own interests are important, that they know everything, are able to get away with everything and that everything will work out fine. Consequently, they miscalculate risks when making decisions (Lovallo \& Kahneman, 2003; Sternberg, 2003, 2007; Gombola \& Marciukaityte, 2007; Ben-David et al., 2010). Each case study illustrates how a leader prone to destructive behaviour failed to recognise the associated risks with their chosen course of action.

Schaubroeck et al. (2007) observed that a core leadership issue is the effect of leaders prone to destructive behaviour on followers. A leader's interest in the people for whom they are responsible to lead, their wellbeing, hopes, fears and aspirations or lack thereof can assist us to differentiate between leaders with low or high leadership capability.

\section{Model Validation}

After conducting the first interviews with study participants, the authors advanced the scope of the destructive behaviour model using Polkinghorne's (1988) methodology. They conversed with three of the study participants who were interested in the destructive behaviour that was the focal point of their final interviews. The authors and study participants examined the implications of combining the two overlapping scopes into four specific and varying notions of 'destructive leader' five different times. This process aligns with Rubin and Rubin's (2005) qualitative methods of reduction and interpretation. The fifth time, study participants found closure with dialogue shifting from the model's development to its application.

Examining the orientation and capability dimensions of the destructive behaviour model helps us to identify a leader as deluded, paranoid, sociopathic or narcissistic. However, study participants recognised that this information did not offer guidance for managing, working with or for a leader susceptible to any of the four forms of destructive behaviour. Study participants concluded that there are no concrete rules when strategising how to manage others' destructive behaviour in leadership roles. Despite this negative observation, study participants did realise that selective interpretation of information, and biased and self-serving appraisals of others may broadly characterise destructive leaders. Therefore, study participants' observations were self-consistent with Mumford et al.'s (2007) conclusions.

Further, study participants observed that leaders prone to destructive behaviour showed no sign at any time of a recognition of the moral consequences of their actions, or if their acts were ethical or unethical. Leaders prone to destructive behaviour were quite simply selfish, focused on their own needs rather than those of either followers or the wider organisation in which they were leading. Thus, study participants' observations were self-consistent with Furnham's conclusions (2010, p. 22). 
Additionally, although the authors specifically associated narcissistic behaviours with one form of destructive behaviour, study participants identified all of the studied leaders prone to destructive behaviour as living under the false impression that others were obligated to serve them and that their own desires should take priority over those of others. As such, the narcissistic level in all destructive leaders' personalities was high and therefore, an underpinning driver of behaviour.

Finally, the authors asked study participants to reflect on the destructive behaviour that they had both witnessed and to which they had been subjected. Within the context of the developed destructive behaviour model, what aspects of behaviour seemed to best characterise leaders prone to destructive behaviour? They are glib and superficially charming. They have a grandiose sense of self-worth, but are also pathological liars, good at conning and manipulating others. They have no remorse about harming others and are emotionally shallow, calculating and cold. They are callous, lack empathy and fall short of accounting for their own actions. Perhaps most importantly, leaders prone to destructive behaviour limited the ability of subordinates to cope with day-to-day problems and consequently, the leader's behaviour was responsible for a shift from a functional to dysfunctional workplace.

\section{Limitations and Implications}

Given the negative impact of destructive leadership, more knowledge is necessary regarding what triggers destructive leadership, Schyns \& Schilling (2013). Although providing some insight into the destructive behavior of leaders, because of its exploratory nature, this inquiry has limitations. It did not examine issues of personal orientation, individual style or locus of control. One could usefully extend this study by focusing on:

- The impact of an extrovert versus introvert personal orientation on leadership behaviour and organisational performance;

- The impact of an optimistic versus pessimistic individual style on leadership behaviour and organisational performance; and

- The impact of an internal versus external locus of control on leadership behaviour and organisational performance.

The study focuses more on the traits and characteristics of leadership (Collins, 2001; Covey, 2004) rather than on the performance of leadership (Drucker, 1995; Yukl, 2006). The study support the thesis that effective leadership calls for multiple intelligence; cognitive, emotional and social as Riggio et al. (2013) argue. The study does not draw on developmental theories (Bennis \& Thomas, 2002), which look at leaders' formative experiences and attempt to draw conclusions about the suitability of those experiences or contingent theories, which seek to identify the leadership requirements of particular organisations, industries or institutions, or situations (Minzberg, 1999). Hence, we only remarked upon the nature of previous leadership experience with the organisation. We require more research in order to determine specific causal linkages. Additionally, the four case study approach limits findings, possibly to the point of their uniqueness to the enterprise under scrutiny, thus emphasising further the need for a broader survey in order to emerge with greater generalised findings.

When considering futures avenues for inquiry or research, it is helpful to reflect on an antecedent of leaders prone to destructive behaviour. Before they derailed, 'destructive leaders' were typically regarded as rising stars and potentially great leaders. However, something went wrong, with self-confident behaviour spiralling out of control into destructive behaviour. Scholars have long noted that attention is critical to self-control (James, 1890; Freud, 1914/1937; Klinger, 1999; Kuhl, 2000) indicating that changes in flow of thought are preceded by an emotionally arousing cue. Consequently, management of distracting cues could facilitate the prevention of out of control behaviour so that one either fails to encode these cues or limits their processing so that they are not fully valued.

However, if "out of control" behaviour is irrational as well as representative of low conscientiousness, this "last-station" effort may be less successful than efforts made well before the last minute temptation. Moreover, our observation is that the problems that we associate with lack of leader's self-control appear to be increasing in the post global financial crisis environment. This environment requires substantial information processing and less job structuring or at least self-structuring (Cascio, 1995; Hunt, 1995). This absence of imposed direction means that the competent leader must create the order for him or her self. He or she must self-manage or self-regulate (Kanfer \& Heggestad, 1997). Moreover, in the turbulent global environment the prevalence and availability of temptation, in the forms of executives' gifts, will continue to aggravate the difficulty of out of control leader behaviour and will challenge leaders' self-control. Executives will need to develop a high level of self reflectivity in order to circumnavigate reinforcement of old behaviour or resist new temptation. 


\section{Concluding Remarks}

A leaning towards destructive behaviour is an unattractive characteristic of any leader, but is a real problem. We would be naïve to act as if there is a cure; however, understanding the types of destructive behaviour can help a leader in his or her hard work to diminish its worst effects in others and by understanding the costs that his or her own destructive behaviour offer the insight he or she requires to lessen its nastiest effects in him or herself.

The model in this article offers perspectives into the nature of destructive behaviour. We acknowledged four types of destructive behaviour that cause deluded, paranoid, sociopathic and narcissistic leader behaviour. By understanding how destructive behaviour seeds itself in others and self offers us some protection. Looking at a leader, we can recognise if his or her leadership orientation is towards self or others and if his or her leadership capability is low or high. Once we have realised the orientation and capability, the model helps us to categorise the type of destructive behaviour a leader might embrace. Furthermore, self-examination can offer the same insight for self.

Ours study provides an enhanced understanding of destructive leadership (Padilla, et al., 2007), its antecedent, personality factors (leadership narcissism and hubris (Hayward \& Hambrick, 1997; Kroll et al., 2000)) and contextual reinforcement (Judge et al., 2006; Padilla et al., 2007) and extends their underplaying theories. Within the context of the model that we presented in this paper, leaders exhibiting deluded behaviour have low capability and are self-oriented. The result is a fragmented approach to leadership in general and organisational change specifically. Organisational damage occurs as those within the organisation are set against each other as they attempt to implement conflicting initiatives.

Leaders exhibiting paranoid behaviour have low capability and are oriented towards others. The result is a reactive approach to leadership in general and an avoidance of organisational change. Organisational damage occurs as a consequence of the organisation becoming progressively more out of step with its external environment.

Leaders exhibiting sociopathic behavior have high capability and are oriented towards others. The result is an efficient, but cold approach to leadership in general and effective implementation of necessary organisational change. Organisational damage occurs as a consequence of the progressively more passive and defensive behaviour of those within the organisation tasked with implementing change.

Leaders exhibiting narcissistic behaviour have high capability and are self-oriented. The result is an approach to leadership that treats the organisation as the leader's private property, with effective implementation of change that is not always organisationally necessary. Organisational damage occurs as a consequence of the leaders over reliance on a sycophantic inner circle, resulting in leadership action that is on occasions inappropriate to the organisation's needs.

To assert that specific responses to leaders prone to destructive behaviour are suitable in situational circumstances is idealistic. In spite of the forwarning that approach is inescapably dependent on the situation, we associate leaders prone to destructive behaviour with miscalculating risks in decision-making and a shift from a functional to dysfunctional workplace (Lovallo \& Kahneman, 2003; Sternberg, 2003, 2007; Gombola \& Marciukaityte, 2007; Ben-David et al., 2010). The study in this paper identified the antecedents of destructive behavior; hubris, a narcissist personality, a recent series of successes and study participants' belief that they were exempt from the rules (Hayward \& Hambrick, 1997; Kroll et al., 2000).

A feature of leaders prone to destructive behaviour is a persistent failure to take responsibility for their own actions. As such, a shift in corporate governance process and practice may help to mitigate the worst excesses of leaders prone to destructive behaviour. As Kakabadse and Kakabadse (2008) advocate, appropriate corporate governance process and practice can foster ethical business conduct, and thus, drive accountability within organisations.

\section{References}

American Psychiatric Association. (2000). Diagnostic and Statistical Manual of Mental Disorders (4th Ed.). Washington, DC: American Psychiatric Association.

Aristotle. (1941). Ethica Nicomachea (Ross, W.D. Trans.), in The Basic Works of Aristotle (McKeon, R. Ed.). New York: Random House.

Ben-David, I., Graham, J. R., \& Harvey, C. R. (2010). Managerial Miscalibration. NBER Working Paper No. 16215.

Bennis, W. (1989). On Becoming a Leader. New York, NY: Addison Wesley. 
Bennis, W. (1999). The leadership advantage. Leader to Leader, 12(Fall), 18-23. http://dx.doi.org/10.1002/ltl.40619991205

Bennis, W. G. \& Thomas, R. J. (2002). Geeks and Geezers: How Era, Values and Defining Moments Shape Leaders. Harvard, MA: Harvard Business Review Press.

Biernacki, P., \& Waldorf, D. (1981). Snowball sampling: problem and techniques of chain referral sampling. Sociological Methods and Research, 10(2), 141-163.

Boddy, C. R. (2011). Corporate Psychopaths. Basingstoke: Palgrave Macmillan. http://dx.doi.org/10.1057/9780230307551

Bryman, A., \& Burgess, R. G. (Eds) (1994). Analyzing Qualitative Data. London: Routledge. http://dx.doi.org/10.4324/9780203413081

Campbell, W.K., Goodie, A.S. \& Foster, J.D. (2004). Narcissism, confidence, and risk attitude. Journal of Behavioral Decision Making, 17: 297-311. http://dx.doi.org/10.1002/bdm.475

Carlson, D., Kacmar, K., \& Wadsworth, L. (2002). The impact of moral intensity dimensions on ethical decision making: assessing the relevance of orientation. Journal of Managerial Issues, 14(1), 15-30.

Cascio, W.F. (1995). Whither industrial and organizational psychology in a changing world of work? American Psychologist, 50, 928-939. http://dx.doi.org/10.1037/0003-066X.50.11.928

Collins, J. C. (2001). Good to Great. New York, NY: Harper Collins.

Covey, S. (2004). Seven Habits of Successful Leaders (Reprinted Ed.). London: Simon \& Schuster Ltd.

Dey, I. (1993). Qualitative Data Analysis: A User-friendly Guide for Social Scientists. London: Routledge. http://dx.doi.org/10.4324/9780203412497

Drucker, P. F. (1995). People and Performance. Oxford: Butterworth-Heinemann.

Drucker, P. F. (2004). What makes an effective executive. Harvard Business Review, No. R0406C, June.

Einarsen, S., Aasland, M. S., \& Skogstad, A. (2007). Destructive leadership behaviour: a definition and conceptual model. The Leadership Quarterly, 18(3), 207-216. http://dx.doi.org/10.1016/j.leaqua.2007.03.002

Flannery, B. L., \& Douglas, R. (2000). Environmental ethical decision making in the U.S. metal-finishing industry. Academy of Management Journal, 43(4), 642-662. http://dx.doi.org/10.2307/1556359

Freud, S. (1914/1937). On Narcissism: an introduction, reprinted in Rickman, J. (Ed.) (1937) A general selection from the works of Sigmund Freud. Psycho-Analytical Epitomes, 1, 118-141.

Furnham, A. (2010). The Elephant in the Board Room. Basingstoke: Palgrave Macmillan. http://dx.doi.org/10.1057/9780230281226

Gombola, M., \& Marciukaityte, D. (2007). Managerial overoptimism and the choice between debt and equity financing. Journal of Behavioral Finance, 8, 225-235. http://dx.doi.org/10.1080/15427560701699510

Hayward, M. L. A. \& Hambrick, D. C. (1997). Explaining the premiums paid for large acquisitions: evidence of CEO hubris. Administrative Science Quarterly, 42(1), 103-127. http://dx.doi.org/10.2307/2393810

Hiller, N. J., \& Hambrick, D. C. (2005). Conceptualizing executive hubris: the role of (hyper)-core self-evaluations in strategic decision-making. Strategic Management Journal, 26, 297-319. http://dx.doi.org/10.1002/smj.455

Hunt, E. B. (1995). Will We be Smart Enough? A Cognitive Analysis of the Coming Workforce. New York, NY: Russell Sage Foundation.

James, W. (1890). Principles of Psychology (Vol. 1). New York, NY: Holt. http://dx.doi.org/10.1037/11059-000

John, O. P., \& Robins, R. (1994). Accuracy and bias in self-perception: individual differences in self-enhancement and the role of narcissism. Journal of Personality and Social Psychology, 66, 206-219. http://dx.doi.org/10.1037/0022-3514.66.1.206

Jones, T. M. (1991). Ethical decision making by individuals in organizations: an issue-contingent model. Academy of Management Review, 16(4), 366-395.

Judge, T. A., LePine, J. A., \& Rich, B. L. (2006). Loving yourself abundantly: relationship of the narcissistic personality to self- and other perceptions of workplace deviance, leadership, and task and contextual 
performance. Journal of Applied Psychology, 91, 762-776. http://dx.doi.org/10.1037/0021-9010.91.4.762

Kakabdase, A. P., \& Kakabadse, N. K. (2001). Essence of Leadership (3rd Ed.). London: Thomson Publishing.

Kakabdase, A. P., \& Kakabadse, N. K. (2008). Leading the Board: The Six Disciplines of World-class Chairmen. Basingstoke: Palgrave Macmillan.

Kakabadse, A. P., Frederic, N., \& Abramovici, N. B. (Eds) (1998). Success in Sight: Visioning. London: International Thomson Business Press.

Kanfer, R., \& Heggestad, E. D. (1997). Motivational traits and skills: a person-centered approach to work motivation. Research in Organizational Behavior, 19, 1-56.

Kernberg, O. (1995). Boarderline Conditions and Pathological Narcissism. Lanham, Maryland, Jason Aronson, Inc.

Kets de Vries, M. (2010). Reflections on Leadership and Career Development. San Francisco, CA: Jossey-Bass.

Kets de Vries, M. F. R., \& Miller, D. (1985). Narcissism and leadership: an object relations perspective. Human Relations, 38(6), 583-601. http://dx.doi.org/10.1177/001872678503800606

King, G. (2007). Narcissism and effective crisis management: a review of potential problems and pitfalls. Journal of Contingencies and Crisis Management, 15(4), 183-193. http://dx.doi.org/10.1111/j.1468-5973.2007.00523.x

Klinger, E. (1999). Thought flow: properties and mechanisms underlying shifts in content, in Singer, J.A. \& Salovey, P. (Eds), At Play in the Fields of Consciousness: Essays in Honor of Jerome L. Singer. Mahwah, NJ: Erlbaum, pp. 29-50.

Kotler, P. (2003). Marketing Management (11th Ed.). New Jersey, NJ: Prentice-Hall.

Kramer, R. M. (2002). When paranoia makes sense. Harvard Business Review, 80(7), 62-69.

Kroll, M. J., Toombs, L. A., \& Wright, P. (2000). Napoleon's tragic march home from Moscow: lessons in hubris. Academy of Management Executive, 14(1), 117-128.

Kuhl, J. (2000). A functional-design approach to motivation and selfregulation: the dynamics of personality systems interactions, in Boekaerts, M., Pintrich, P.R. \& Zeidner, M. (Eds), Handbook of Selfregulation. San Diego, CA: Academic Press, pp. 111-169. http://dx.doi.org/10.1016/B978-012109890-2/50034-2

Kwon, T. S. (2003). The IMF must learn from its mistakes. Financial Times, 14th August: 7.

Li, J., \& Tang, Y. (2010). CEO hubris and firm risk taking in China: the moderating role of managerial discretion. Academy of Management Journal, 53(1), 45-68. http://dx.doi.org/10.5465/AMJ.2010.48036912

Lincoln, Y. S., \& Guba, E. (1985). Naturalistic Inquiry. Beverly Hills, CA: Sage.

Lovallo, D., \& Kahneman, D. (2003). Delusions of success. Harvard Business Review, July: 56-63.

Lowe, K. B. (2003). Demands, constraints, choices and discretion: an introduction to the work of Rosemary Stewart. The Leadership Quarterly, 14, 193-238. http://dx.doi.org/10.1016/S1048-9843(03)00009-2

May, D. R., \& Pauli, K. P. (2002). The role of moral intensity in ethical decision making. Business Society, 41(1), 84-117. http://dx.doi.org/10.1177/0007650302041001006

McCracken, G. (1988). The Long Interview. Beverly Hills, CA: Sage.

Miles, M. B., \& Huberman, A. M. (1984). Qualitative Data Analysis: A New Sourcebook of Methods. Beverly Hills, CA: Sage.

Minzberg, H. (1999). Managing quietly. Leader to Leader, 12(Spring), 24-30. http://dx.doi.org/10.1002/ltl.40619991206

Mumford, M., Espejo, J., Hunter, S., Bedell-Avers, K., Eubanks, D., \& Connelly, S. (2007). The sources of leader violence. The Leadership Quarterly, 18, 217-235. http://dx.doi.org/10.1016/j.leaqua.2007.03.005

Padilla, A., Hogan, R., \& Kaiser, R. B. (2007). The toxic triangle: destructive leaders, vulnerable followers, and $\begin{array}{llll}\text { conducive environments. } & \text { Leadership 176-194. }\end{array}$ http://dx.doi.org/10.1016/j.leaqua.2007.03.001

Polkinghorne, D. E. (1988). Narrative Knowing and the Human Sciences. New York, NY: State of New York University Press.

Raskin, R., \& Hall, C. S. (1979). A narcissistic personality inventory. Psychological Reports, 45, 590. 
http://dx.doi.org/10.2466/pr0.1979.45.2.590

Raskin, R., \& Terry, H. (1988). A principal-components analysis of the narcissistic personality inventory and further evidence of its construct validity. Journal of Personality and Social Psychology, 54(5), 890-902. http://dx.doi.org/10.1037/0022-3514.54.5.890

Raskin, R., Novacek, J., \& Hogan, R. (1991). Narcissistic self-esteem management. Journal of Personality and Social Psychology, 60(6), 911-918. http://dx.doi.org/10.1037/0022-3514.60.6.911

Rhodes, C., \& Brown, A. D. (2005). Narrative, organizations and research. International Journal of Management Reviews, 7(3), 167-188. http://dx.doi.org/10.1111/j.1468-2370.2005.00112.x

Riessman, C. K. (1993). Narrative Analysis. Newbury Park, CA: Sage.

Riggio, R. E., Murphy, S. E., \& Pirozzolo, F. J. (2013). Multiple Intelligences and Leadership. New York, New York, Psychology Press.

Rubin, H. J., \& Rubin, I. S. (2005). Qualitative Interviewing: The Art of Hearing Data (2nd Ed.). Thousand Oaks, CA: Sage.

Schaubroeck, J., Walumbwa, F., Ganster, D., \& Kepes, S. (2007). Destructive leaders traits and the neutralizing influence of an 'enriched' job. The Leadership Quarterly, 18, 236-251. http://dx.doi.org/10.1016/j.leaqua.2007.03.006

Schyns, B., \& Schilling, J. (2013). How bad are the effects of bad leaders? A meta-analysis of destructive leadership and its outcomes. Leadership Quarterly, 24(1), 138-158. http://dx.doi.org/10.1016/j.leaqua.2012.09.001

Sheard, A. G., Kakabadse, A. P., \& Kakabadse, N. K. (2009). Leadership Teams: Developing and Sustaining High Performance. Basingstoke: Palgrave Macmillan. http://dx.doi.org/10.1057/9780230239487

Sheard, A. G., Kakabadse, N. K., \& Kakabadse, A. P. (2013). Visceral behaviours and leadership: a dark side of boardroom life? Journal of Management Development, 32, 18-35. http://dx.doi.org/10.1108/02621711311286900

Singer, M. S., \& Singer, A. E. (1997). Observer judgments about moral agents' ethical judgments: the role of scope of justice and moral intensity. Journal of Business Ethics, 16(5), 473-484. http://dx.doi.org/10.1023/A:1017992805903

Sternberg, R. J. (2003). WICS: a model of leadership in organizations. Academy of Management Learning and Education, 2(4), 386-401. http://dx.doi.org/10.5465/AMLE.2003.11902088

Sternberg, R. J. (2007). A systems model of leadership. American Psychologist, 62(1), 34-42. http://dx.doi.org/10.1037/0003-066X.62.1.34

Stuart, R., \& Lindsay, P. (1997). Beyond the frame of management competencies: towards a contextually embedded framework of managerial competence in organisations. Journal of European Industrial Training, 21(1), 26-33. http://dx.doi.org/10.1108/03090599710156410

Svensson, G., \& Wood, G. (2006). Sustainable components of leadership effectiveness in organizational

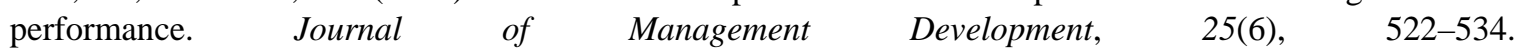
http://dx.doi.org/10.1108/02621710610670100

Yukl, G. A. (2006). Leadership in Organizations. Upper Saddle River, NJ: Prentice Hall.

\section{(cc) EY}

This work is licensed under a Creative Commons Attribution 3.0 License. 